\title{
David Oliver: England's social care models harm the poorest areas
}

\author{
David Oliver consultant in geriatrics and acute general medicine
}

Berkshire

Current models of local government funding systematically disadvantage people in deprived areas, compounding already entrenched health inequalities. ${ }^{1}$ The Joseph Rowntree Foundation found in 2015 that the most deprived English local authorities had experienced cuts of $£ 182$ more per head than the most affluent, "breaking the historic link between the amount a local authority spends per head and local deprivation levels." ${ }^{23}$

A 2018 analysis showed that 25\% of services in England's most deprived local authority areas were rated inadequate by the Care Quality Commission, compared with only $15 \%$ in the 10 most affluent areas. ${ }^{4}$ It was published by the Labour Party's research team, but the conclusions are compelling.

Local government relies on three main sources of income ${ }^{5}$ : direct support grants from national government, business rates, and local council tax, based on the estimated value of privately owned residential properties. In December 2017 the government gave local authorities the permission to raise an additional $3 \%$ of council tax as a specially earmarked "social care precept" to help tackle social funding gaps locally. ${ }^{6}$

The more affluent the area, the higher the property values-hence the greater ability to raise income through council tax and precept. Income from business rates is generally higher in local authorities with thriving economies and higher employment rates. ${ }^{7}$ Affluent areas also have a higher proportion of homeowners and so commit a lower percentage of spend to publicly owned council housing for rental.

The 2010-15 coalition government reduced support grants to all local authorities, with the National Audit Office reporting a funding reduction of $28 \%$ from 2010 to $2014 .{ }^{8}$ Central funding support for local government is projected to fall by $77 \%$ by $2020 .{ }^{9}$ Council social care spending decreased by an estimated $13 \%$ from 2010 to $2016 .{ }^{10}$ Independent estimates show that around 400000 fewer people were in receipt of social care in 2016 than in $2010 .{ }^{11}$ Unlike the NHS, such care is already rationed, based on strict eligibility criteria that exclude people with lower level needs, and is means tested. These cuts affect citizens' lives, whether care recipients or family carers. ${ }^{12}$
Old age is a key driver of care needs, and relatively affluent areas often have a higher proportion of older residents. But people in more socioeconomically deprived groups have much shorter disability-free or healthy life expectancy after 65 , so they may meet the threshold of need earlier. ${ }^{13}$ And wealthier areas will have more people who cross the means testing threshold for "self funding" their care, meaning less responsibility for local government.

Current social care funding models don't match population need. They exemplify the "inverse care law" first described by Julian Tudor Hart, ${ }^{14}$ whereby those most in need receive the poorest access to care. They also render council tax regressive-further entrenching gaps between provision for rich and poor. ${ }^{15}$ None of this aligns with national policy ambitions to prioritise prevention, reduce inequalities, and improve population health. ${ }^{1617}$

Current social care funding models don't match population need. They exemplify the inverse care law'

The 2010 Labour and 2017 Conservative general election manifestos both contained proposals to use property value, even posthumously, to fund care. This would be a progressive move, as it would effectively tax wealth, not income, and would reduce inequalities reinforced by family wealth passing down to younger generations. Both proposals—crudely labelled by opponents as the "death tax" or "dementia tax"-were vigorously opposed and quickly binned.

The prime minister's recent commitment to increase funding to NHS England by 3.4\% a year did not include local government, public health, or social care ${ }^{18}$ So, let's hope that the Department of Health and Social Care's ongoing review ${ }^{19}$ and resulting green paper can consider some radical solutions to reduce inequalities in social care provision, not entrench them.

Competing interests: See www.bmj.com/about-bmj/freelance-contributors/davidoliver.

Provenance and peer review: Commissioned; not externally peer reviewed. 
1 Local Government Association. A matter of justice: local government's role in tackling health inequalities. Feb 2018. https://www.local.gov.uk/sites/default/files/documents/1. $42 \% 20$ public\%20health\%20inequalities_web.pdf.

2 Case R. The most deprived areas have borne the brunt of local government budget cuts. Joseph Rowntree Foundation. 11 March 2015. https://www.jrforg.uk/press/most-deprivedareas-have-borne-brunt-local-government-budget-cuts.

3 Sergeant M. Labour: Spending cuts hit most-deprived areas hardest. BBC News 30 Jan 2014. https://www.bbc.co.uk/news/uk-politics-25953444.

4 Savage M. New data confirms postcode lottery of care for the old. Guardian 3 June 2018. https://www.theguardian.com/society/2018/jun/03/data-confirms-postcode-lottery-carefor-the-old.

5 Local Government Information Unit. Local government facts and figures. https://www.lgiu. org.uk/local-government-facts-and-figures/.

6 Ministry of Housing Communities and Local Government; Javid S. Government sets out further measures to support councils to deliver services. 19 Dec 2017. https://www.gov. uk/government/news/government-sets-out-further-measures-to-support-councils-to-deliverservices.

7 Aldrick P. Letting councils keep rates revenue "divisive." Times 1 March 2018. https:// www.thetimes.co.uk/article/letting-councils-keep-rates-revenue-divisive-rvgr8r3tc.

8 National Audit Office. The impact of funding reductions on local authorities. 19 Nov 2014 https://www.nao.org.uk/report/the-impact-funding-reductions-local-authorities/.

9 Bounds A. Local councils to see central funding fall $77 \%$ by 2020 . Financial Times 4 July 2017. https://www.ft.com/content/9c6b5284-6000-11e7-91a7-502f7ee26895. [Login needed.]

10 Institute for Fiscal Studies. Health Foundation. Securing the future: funding health and social care to the 2030s. May 2018. https://www.ifs.org.uk/uploads/R143.pdf.

11 King's Fund. Social care for older people: home truths. 15 Sept 2016. https://www. kingsfund.org.uk/publications/social-care-older-people.
12 Richmond Group of Charities. Real lives. Sept 2016. https://richmondgroupofcharities. org.uk/sites/default/files/lr 5285 the richmond group social care real lives_report.pdf. 13 Age UK. Improving later life: vulnerability and resilience in older people. 2015. https:// www.ageuk.org.uk/globalassets/age-uk/documents/reports-and-publications/reports-andbriefings/health--wellbeing/rb_april15_vulnerability_resilience_improving_later_life.pdf.

14 Appleby J, Deeming C. Inverse care law. King's Fund. 21 June 2001. https://www. kingsfund.org.uk/publications/articles/inverse-care-law.

15 Inman P. Scrap "highly regressive" council tax, says thinktank. Guardian 20 March 2018. https://www.theguardian.com/money/2018/mar/20/scrap-highly-regressive-council-taxsays-thinktank

16 Ham C, Murray R. Implementing the NHS five year forward view: aligning policies with the plan. King's Fund. 18 Feb 2015. https://www.kingsfund.org.uk/publications/ implementing-nhs-five-year-forward-view?

gclid=EAlalQobChMlhcra9tLn2wIVw7TtCh0RxgRIEAAYASAAEgJ8M D BwE.

17 Public Health England. Strategic plan for the next four years: better outcomes by 2020 . April 2016. https://assets.publishing.service.gov.uk/government/uploads/system/uploads/ attachment_data/file/516985/PHE_Strategic_plan_2016.pdf.

18 Edwards N. Funding settlement a big step forward but PM's world-class NHS difficult to achieve. Nuffield Trust. 17 June 2018. https://www.nuffieldtrust.org.uk/news-item/funding settlement-a-big-step-forward-but-pm-s-ambition-for-world-class-nhs-difficult-to-achieve.

19 Brindle D. Delay to green paper caps dismal 48 hours for social care. Guardian 19 June 2018. https://www.theguardian.com/social-care-network/2018/jun/19/delay-green-papersocial-care.

Published by the BMJ Publishing Group Limited. For permission to use (where not already granted under a licence) please go to http://group.bmj.com/group/rights-licensing/ permissions 